\title{
Transformation of Ishak Pasha Palace
}

\author{
B. Yildirım \\ Department of Landscape Architecture, \\ Istanbul Technical University, Turkey
}

\begin{abstract}
This research analyses the transformation of the historic Ishak Paşa Palace, chronologically starting from its almost-a-hundred-year construction period of 1685-1784, through the damages it suffered from wars, invasions and improper restorations of the 19th and the 20th century, and the recent restoration work finished by 2009. Carrying architectural characteristics of Ottoman and Seljuk civilizations, the palace's uniqueness also comes from its central heating systems documented as one the first examples of its kind in the world and its location on the Silk Road in Doğu Beyazit province of Turkey. Starting from the Russian siege in 1828 and the following wars, invasions the palace suffered from several damages. Not until 1966, after the announcement of its preservation by the Directorate of Monuments and Museums in 1963, the projects for restoration, the first of which included a general clean up, excavation of the site and maintenance of the East and South facades, started to be developed. Restoration works continued until 2007 and it was reported that improper restorations which were damaging the palace had been taking place during the last 48 years. In 2007 once again the palace has undergone another restoration which covered the whole palace with a roof of huge wooden beams and laminated glass visually blocking the perception of the palace both from inside and outside. In the year 2011 a new contract was issued for the restoration of the palace. The article aims to discuss mainly the restoration projects that have transformed Ishak Pasha Palace and have given it its current appearance, within the last 48 years, on the bases of its historical background, an embodiment of a variety of architectural styles together with the wars and invasions it had gone through.
\end{abstract}

Keywords: Ishak Pasha Palace, Doğubeyazlt, restoration, damage, history, transformation, Silk Road. 


\section{Introduction}

Ishak Pasha Palace is located at Doğubeyazıt County which is $97 \mathrm{kms}$ to Ağrı Province. Doğubeyazit is at a $2.505 \mathrm{sqkm}$ tableland/plateau which is surrounded by Ararat Mountain, Little Ararat Mountain, Pamuk and Ziyaret Mountains. This region is placed at the well-known historical Silk Road which connects Asia to Europe and has changed hands between the border states [1]. The oldest findings relating to the region's history are the rock tombs which are placed at the west slope of Doğubeyazıt castle and were discovered by the French explorer Charles Texier in 1830, dating between 13th and 9th century at Urartian era [1]. The terrarosa ceramic pieces that were found at the southeast and southwest of the Doğubeyazıt castle during the first surface analysis carried out between 1978 and 1979, dating to the Urartian era were taken as significant to the location of the first settlement that was Urartian, around the area [2]. Although there is no finding on the subject, Bingöl mentions, depending on Doğu Beyazit's locating on the Silk Road which dates back before the Urartian era that the first settlements might have dated before the Urartians.

After the end of the Urartian rule, Medes, Persians, Romans, Byzantians, Sasanians and Arabians ruled the region. After going under the rule of Great Seljuk Empire in 1064, Doğubeyazıt was ruled by Ilkhanids, Celayirs, Karakoyunlus, and Timurids until the 13th century [3]. Going under Ottoman rule after Çaldıran War in 1514, until 1578 control of the region changed hands between the Ottomans and Safavids. During the emperorship of Murat, the 4th, the construction of Ishak Pasha Palace was initiated by Çolak Abdi Pasha who had given the governorship of the sanjak Beyazit [10]. The construction of the Palace had continued during the governorships of Abdülfettah Efendi (death 1711) and Mahmut Pasha (death 1767) until being finalized during the governorship of Ishak Pasha, the 2nd [4].

On the inscriptions placed at the top of the main entrance door of Harem and at the left and right cells, it is stated that the Palace was dated as exilic 1199 (Gregorian calendar, 1784). The date 1214 that is on the inscriptions placed at the tomb housing two graves within, and its coinciding with the date of death of II. Ishak Pasha supports the views that, these were graves of Ishak Pasha, the second together with his wife and were built 15 years after the construction of the palace [3].

The magnificence of the Palace had attracted many travellers so that it took its place within the travel books and engravings of the time. In 1805, French agent P. Amédéé Jaubert who had been sent to Persia by Napoleon, had traveled in the region and had to spend some time in the dungeon of the Palace when caught. Afterwards, P. Amédéé Jaubert had included Beyazıt and Ishak Pasha Palace in his travel book [5].

With Russian Invasion of 1828, the peaceful period of Beyazit sanjak had come to an end and the era of wars and invasions which caused major damage to the palace had started. Although Russian invasion lasted for one year, the palace had serious damage [3]. The gold plated doors of Harem together with the books and documents from the library of the Palace had been taken away to Russia. It 
is known that these documents among which there had been the ones on the construction phases and history of the palace were placed in Leningrad Museum [6]. In 1854, during the Crimean War, Doğubeyazit was invaded for the second time by the Russians and the palace was vandalized again [4].

In the '93 War known as Ottoman and Russian War of 1877-1878, Doğubeyazıt and its surroundings were left to Russians. Russian invasions continued until the end of 19th century. During the First World War, the palace was used as a military post by Russians and deformed by the additions. In addition to that, the walls of the palace were covered by nearly $1.5 \mathrm{~cm}$-thick tar and flue dust caused by the fires for cooking within inappropriate areas without chimneys because of the inadequacy of the kitchen and the burn out of the sugar sacks placed in the kitchen warehouse [3]. Beyazid was under the rule of the Russians until Bolshevic Invasion. The Palace was used as a cavalier military post between 1925 and 1937 [7]. İ. Zühtü, in his article published the Arkitekt Journal in 1934, mentions that the stones blocks from the ceremony hall and harem rooms were taken away as spolia for the courtyard walls of the surrounding mansions [8]. As a result the palace had reached the 20th century seriously damaged through wars, misuse, fires and plundering [9].

\section{Presentation of the palace}

\subsection{Topographical location of the palace}

The Palace has been subject to engravings and travel books of many travellers of the time with its location at the slopes of the old Beyazit city resembling an eagle's nest. C. Barry who had visited the Palace in the 19th century had written that the Palace was located at the slope of the mountain formed of red marble stones resembling an amphitheatre [10].

The Palace is located on a $7600 \mathrm{~m}^{2}$ platform which was formed by a sharp flattening of the topography. The outside dimensions of the mass palace complex are $115 \mathrm{~m}$ and $50 \mathrm{~m}$. The Palace with its coutyarded plan schema, gives references to Ottoman palace typology [1].

The correlation between plan schema and topography of the Palace shows that the need for defence had been taken into consideration [3]. This concern for defence can be clearly seen with the high, massive walls facing north, south and west directions opening to the valley, and with the decision to preserve the sharp limestone rocks instead of a levelling operation for a wide flat entrance area together with the watch towers built on both sides of the main courtyard.

\subsection{Architectural features of the palace}

The palace is situated on top of a hill on a level platform and is composed of three sections: one forecourt (biderun) and two inner courts (enderun).

The function of the forecourt was similar to the function of the first court of Topkapı Palace. The daily activities took place here and the administrative decisions were announced to the public in this courtyard. 
Basic equipment and supplies were stored in the buildings surrounding the courtyard which also housed the palace guards as well as the front-line services.

The courtyard is open to public and is reached through the magnificent gate, set in the eastern façade. Eastern façade is constructed of blind calcareous moulding stone. Entry to the palace is possible only through this gate.

Inside the courtyard, the wall widens towards the south of the gate. Three guard rooms are located at this section. To the left of the entrance, there is fountain and a basin stone. Water still flows to the basin inside soil pipes.

Guards' dormitories are situated on one side of the north wing and are separated by a thick wall. The prisons are built below the dormitories. There are six cells positioned in a north-south orientation. French traveller A. Jaubert was imprisoned in these cells between 1805 and 1806. Jaubert's travel journal was published in Paris, in 1921. He describes the prison as a " 16 feet long, 5 feet wide, 30 feet deep dungeon. The corpses of deceased prisoners were scattered on the soil floor" [7]. The stables were situated on the south wing of forecourt where horses of important guests and ambassadors were kept. A coach house was also located here.

Access to the inner courtyard is opposite the main gate (taç kapı) and through a barrel vault. The servants' quarters are to the south of the inner courtyard. These buildings are heavily damaged [1].

The gate of the inner courtyard (enderun) is on the East wing. This wing connects the North and South Wings of the courtyard. To the North of the East Wing, situated on the ground floor, is a guards room and, on the upper level, is the gallery of the reception hall. On the south side of the gate there are three guards' rooms and a presentation hall.

The selamlik (men's room) is on the north wing of the courtyard. Selamlik is a common feature of Ottoman architecture - seen in both public and private buildings. Ottoman palace tradition did not allow the guest to come into contact with any part of the private life in the palace. The concepts of "Haremlik" and "Selamlık" were born out of this need. Guest were received and welcomed in Selamlık rooms. In time, Selamlık turned into a "men-exclusive" zone [1].

In Ishak Pasha Palace, selamlik is situated on the inner courtyard along with the mosque, the servants' rooms and the guest rooms, integrating it into the palace functionality.

The mosque is among the most important buildings in the whole palace compound. It is right across the hall leading to the Council Chambers (Divan). The entrance to the mosque - on the west façade of main hall - is decorated with moulding and botanical designs. The mosque has a square plan and its dome is central. The weight of the dome is distributed on four piers with supporting pendentives. There are three towers marking the boundary of the dome outside on the roof. The single minaret rises from the northwest corner of the dome. Inside the main prayer hall, there is a simple but eye-catching mihrab decorated with heavenly descriptions. To the east of the mihrab, a pulpit grows out organically from the façade. The steps leading to the minaret are interrupted with a landing which provides access to the women's praying area, situated on the north façade of mosque. There is a passage from this area to harem. Considering 
the age that it was constructed, the general belief manifests that the minaret was the work of common and self-taught masters [1].

The madrasah is to the north and is designed as a continuance of the mosque. It is a rectangular shape. The madrasah is a school for training the children of palace gentlemen and other residents but its inter-connecting concept indicates that its prayer (namaz) section was constructed to provide an extension to the mosque's capacity on important days [1]. The madrasah has a terrace that is composed of upper floors of a harem section. The view from the terrace, overlooking the Karaburun Hills and Doğubeyazıt Castle, is excellent. It is thought that the terrace, which can only be accessed from the harem, was designed for the use of harem residents but it can also be used as a vantage point for the defence of the palace when necessary.

There is a small but impressive mausoleum (türbe) on the northwest corner of the courtyard. Although it is built in the style of the Seljuk kümbet (cupola) architecture, its octagon plan reflects the Ottoman style and its ornaments, the Caucasian motifs [1].

Inside the mausoleum, below the ground level there is rectangular burial vault. The vault is ventilated by two ventilation chimneys at the ground level. The walls surrounding the tomb do not exist today. The top of cupola is ruined and the metal crescent which would have been on the top of the cupola, has been stolen. The condition of the burial vault is also poor [1].

The Harem section, also accessed from the second courtyard, is the most complex and crowded portion of the palace. Harem quarters were exclusive to the pasha and his family; strangers were forbidden to enter. Its architectural plan and the way the daily life was organised resembles the harem in the Topkap1 Palace. Due to topographic reasons harem is $0.8 \mathrm{~m}$ higher than the other sections of palace. On the ground floor of harem there is a kitchen, a hamam and toilets as well as the harem rooms [12]. Upper floor(s) of Harem did not survive. However, the structural clues and ancient gravures indicate that, originally, at least one floor and perhaps a second but smaller floor above the ground floor [1].

The plan of the harem complex is rectangular with an east-west orientation. In the centre of the complex there is large multi-purpose hall where the Pasha's private daily activities took place and private gatherings were organised. The main entrance to the hall is from the reception room in the main entrance hall. Religious festivals and circumcision party's were also held in this hall. This hall functions like a "sofa" space which is the central characteristic of the traditional Turkish house. The entertainment shows performed by the concubines are reflected on its architectural design. The huge backboard on the façade and rich ornaments on windows mesmerized the travellers. Wagner reported that during his visit to the palace in 1841, the walls of the hall were covered with mirrors and gilts and this captivating portrait was in full contrast with the poverty of city [13]. The structure did not reach our day but it is thought that timber and iron materials were used in its construction. The hall had no windows so it is thought that it was lit by skylights in the ceiling [4]. In its plan the hall creates a feeling of triple division with its two three-pointed arches. 
The side façade of hall is built of cut stone, using black and yellow calcareous stone, reaching to a height of 1.28 meters from the floor. The decorative pattern on the wall continues up to a molding cornice at the top. The decorative concept is also evident inside the hall, bordering the arches and the windows opening to the corridor, also around the recesses that housed the mirrors. The mirrors positioned within blind windows illuminate the hall by reflecting the light reaching from skylights above. Flowing out from the windows on north façade, this light also provides the lighting of the north corridor [14].

Hamam is situated on the south of sofa hall. Sticking to the traditional hamam pattern, Ishak Pasha Palace's hamam is situated in a west-east orientation and includes the warm room, hot room and cooling room together with the furnace. A person taking a bath washes in the hot room, gets dressed in the cooling room and rests. Furnace section, on the east of hot room, has a rectangular plan.

On the base of this section covered by a vault there is a simple furnace and heating section on the stove. Hot (caldarium) and cold rooms and the furnace section which are found in larger hamams are present here, albeit in a smaller scale. The marks of soil pipes on the walls make it obvious that the furnace did not only heat the caldarium [3]. G. Goodwin discovered that a sort of centralheating system reached other parts of the palace through a network of pipes [1]. It is known that the two soil pipes, measuring $0.14 \mathrm{~m}$ in diameter, run the length of the tunnel (situated at the northwest corner of front courtyard), they go under the council room and reach the mosque. The pipes branch out at this point, one going along the western façade towards the private gardens, the other to the sofa hall and the rooms in front of the hall. The pipes provided under floor heating system for these rooms. The servants' rooms, which were not connected, were heated by stoves or fireplaces.

The kitchen is situated on the south of the hamam. It is evident from the plan of the Ishak Pasha Palace that the kitchen inter-connected with the hamam and the sofa hall whilst serving both the harem and selamlik. The kitchen door, which was located at the south east corner of the long corridor leading to the harem compound, served the second courtyard (selamlık). The door on the north west corner of the kitchen served the harem. Interior decoration of the kitchen is lost but the architectural were preserved [1]. To the east of kitchen there are three rooms for the cooks. Inside two of these rooms there two pools built with cut stones. These pools were used as fridges. Perishable food items were stored under the water inside the pools [3].

There are harem rooms on the north and east facades of sofa hall. These rooms extend outside via two windows within deep alcoves and round arches. There is a stove between two arches. Inside the second and third rooms (located on north west corner), there are pools, measuring $400 \mathrm{~cm}$ by $50 \mathrm{~cm}$ and $35 \mathrm{~cm}$ deep, made of calcareous cut stone. Filled with either water or snow, these pools were used to cool the drinks [1].

On the south side of the sofa hall, there is a staircase leading down to a small door which opens to the outer gardens of the harem. 
The important structures of the harem compound, the kitchen, hamam, the sofa hall did not suffer much damage but the upper floors have disappeared totally.

However, the illustrations by the French archaeologist, Charles Texier clearly show that the harem had a two-storey structure with a flat roof [11]. The second floor of the harem overlooked the inner courtyard. The constructional marks on harem façade and Texier's illustrations provide evidence for the existence of a half storey over the main gate. We can also tell that there were small wooden mansions featuring overhanging bay windows (cumba) to the right and left of the gate [11]. Bay window (cumba) is a common feature of the Ottoman architecture, providing a secure vantage for the women of harem from which they could view the outside without being seen.

Of the few wooden ornamental features around the palace, only four consoles survived to the present day. These are wooden supports extending horizontally out of the floor of one of the north facing selamlı rooms and they carried the balcony which does not exist now. Each support is carved into eagle and lion figures at the top and a human figure at the bottom. The figures represent power and sovereignty [15].

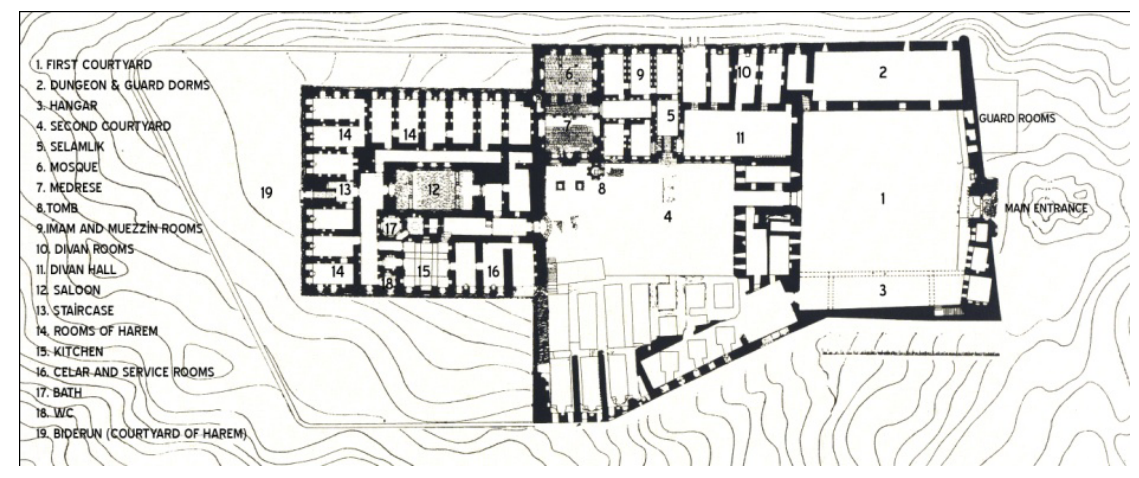

Figure 1: $\quad$ The plan of Ishak Pasha Palace, revised [1].

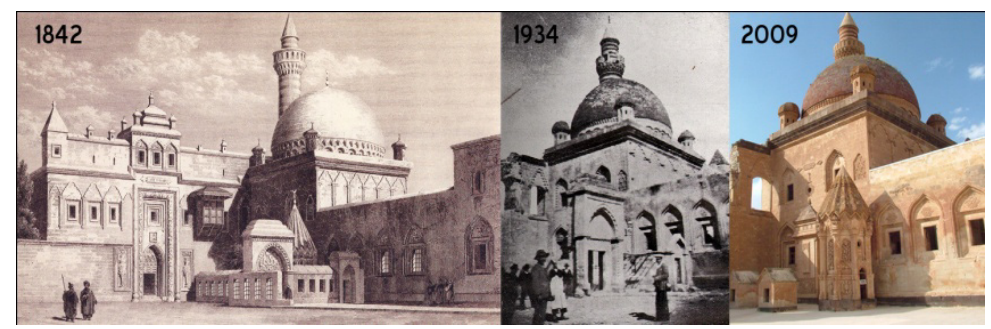

Figure 2: The Transformation of the mausoleum in years $[8,11]$.

It is believed that, with its plan, the architectural style and the functional inter-connection of separate zones of the palace, Ishak Pasha is a replication of Ottoman Palace tradition $[1,3,12]$. Palace ornamentations and architectural 
elements, on the other hand, reveal the influence of Seljuk and Caucasian styles in particular, as well as Ottoman [1]. The impact of the westernized $18^{\text {th }}$ century Istanbul culture are present in baroque, rococo, imperial style architectural elements and decorations [3]. In Ishak Pasha Palace the diverse styles and spatial designs were selected creatively and revitalized through traditional values.

There are several explanations for the mixture of different and vast range of styles taken from different historical and geographical backgrounds. The owner of the palace, Ishak Pasha, was an Istanbul gentleman accustomed to the tradition of Ottoman Palace and exposed to the prevalent $18^{\text {th }}$ century styles. Eastern influences were also prevalent. Doğubeyazıt town is close by. It is a border town at the east of the empire and it is on a transit road connecting Asia to Europe. Different cultures clashed and merged in this part of the world. Also, the Çıldıroğlu clan wished to stress their power and independence from Iran, Russia or the Ottomans and expressed their wish by building a magnificent new palace [1]. Ishak Pasha Palace, where diverse architectural styles, traditions and materials exist in harmony, will continue to illuminate the past and enlighten the future.

\section{The $20^{\text {th }}$ century excavations and restoration work}

General Dictorate of Monuments and Museums is the first institution that for the protection of cultural assets, founded in 1951 with the law 5805 [16]. The development plan law of 6785 , enacted in 1957 together with the historic monuments law of 1710, enacted in 1973, has shown that conservation consciousness has started and conservation issues have started to be taken into consideration. So until 1960s, it was not possible to mention any kind of institutionalized and conscious effort in order to protect historic and traditional environments [16]. This delay in institutionalization caused many historical buildings' break down and sudden destruction [16]. Ishak Pasha Palace had also been abandoned like other cultural assets in Turkey until 1956-1958 when the first evaluations on conservation have been initiated [17].

The first survey study was carried out by Mahmut Akok who was assigned by the newly established Survey Bureau of General Directore of Monuments and Museums in 1956 [4]. After the survey prepared by Akok, the cleaning and restoration of the ruined parts of the Palace were started between 1960 and 1961. Those interventions that were carried out without detailed examination and excavations were for repair and conservation purposes [9]. Small-scale restoration work continued until 1984 when the palace has become the object of attention with a paper, Gündoğdu presented in the Symposium of National Palaces, mentioning the importance and necessity of a more comprehensive restoration project [18]. Not until 1992 The Ministry of Culture has taken action and the first comprehensive restoration project of the Palace has initiated by Kaba Construction Firm.

Still, some minor cleaning and quick namely-restoration-work had been initiated before the restoration project was finished and approved by Erzurum Council for the Protection of the Cultural and National Property [18]. In 1994, 
upon the completion of restoration project, unwanted interventions and applications by the Contractor Firm since 1992 were pulled down and the restoration was initiated. First of all, the walls that were repaired by the concrete mortar were pulled down and rebuilt using lime mortar [9]. Except for the ones of Harem part, all the walls were restored with cut stones [18].

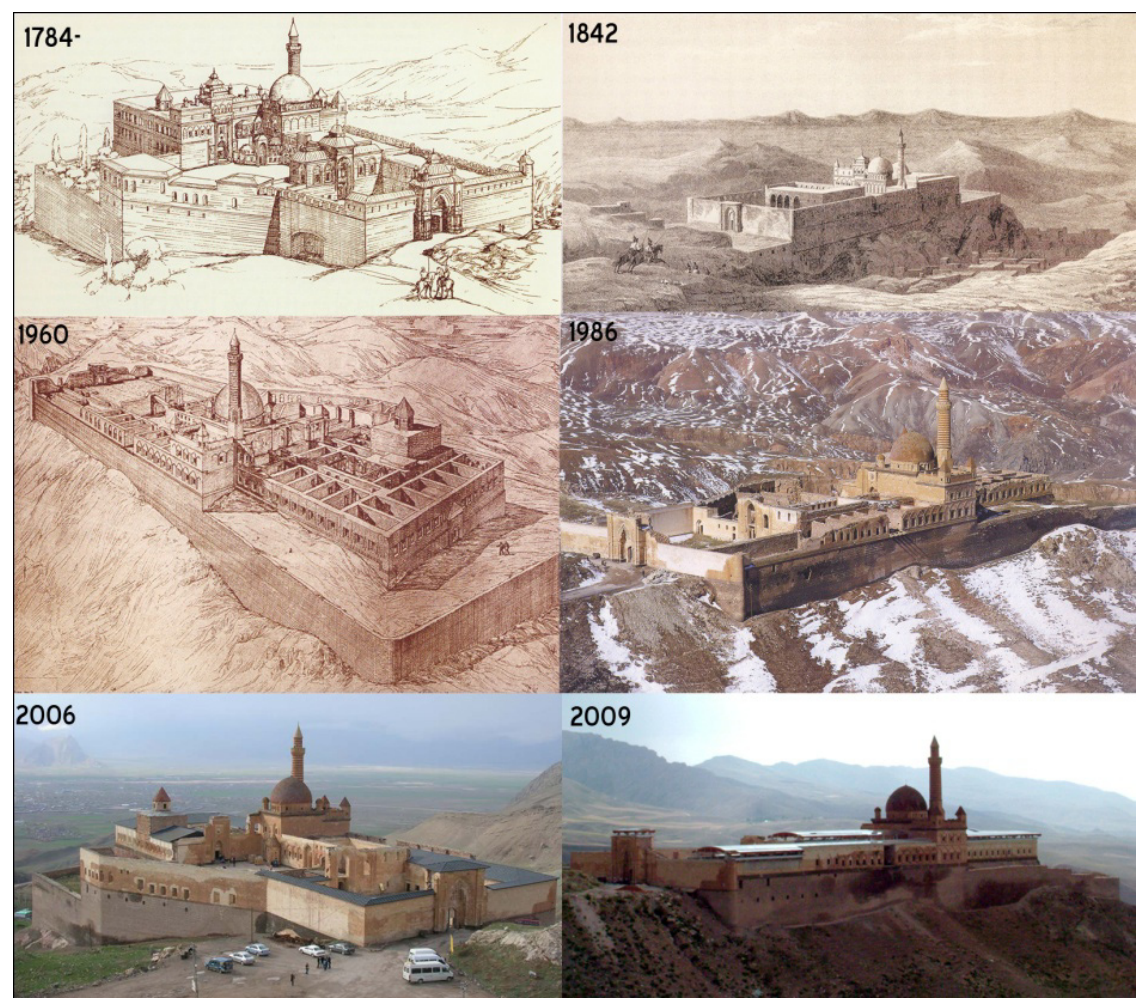

Figure 3: Transformation of Ishak Pasha Palace through the years, 1784 [4] reconstruction of the palace (drawing by M. Akok), 1842 [11], 1960 [4], 1986 [4], 2006 [20, 21].

The excavations were neither precise nor scientific enough as the payment to the contractor had already been made before the work had been completed [16]. The hasty attempts to finalize the restoration work, resulted in the conclusion of restoration without having detailed excavations causing a loss of critical data [18]. With the efforts of Hamza Gündoğdu, the scope of work tried to be expanded and new findings were obtained. Studies continued in Harem section and second court.

As a result of the work carried out in the Harem section, the heightened walls were pulled down to their normal sizes; all the parts except for the ceremony hall were covered by wood construction inclined sheet roof. However, snow and rain penetration could not be prevented because of the short roof eaves. A plexy glass 
roof was planned for the ceremony hall but could not be constructed as not being included in the original restoration project [18]. Harem court was taken to ground floor and the ruins were cleaned. During the cleaning up of the court down to the original cobblestone pavement, the drainage pool and clay pipes carrying water to the complex were discovered [9]. Although this courtyardgarden in the south west of Harem might be considered as corresponding to the private garden of the Sultan (Hasbahçe) in Ottoman Palace tradition, no tree roots were found. Harem sewage was discovered in the middle part of this courtyard near the kitchen. In addition, two cut-stone cisterns for the storage of water and food, having regular staircases were found under close to the entrances of service rooms of the kitchen. During test trench and excavations at the second courtyard, vaults were discovered at $12 \mathrm{~m}$ depth. Due to a static problem, the walls of the vaults and basements were reinforced by steel structures [18].

Through the restoration work carried out in the first courtyard, the dungeons were cleared from rocks, soil and ruins, entrance stairs were renewed, concrete mortar of 1992 on the cell walls were cleaned and the walls were re-bonded with lime mortar. The flooring of the Military Post placed on top of the dungeon was renewed. The walls were strengthened/reinforced and the space was covered by a wooden roof. However, this roof did not cover the whole space and the structure remained weak. In parallel to the excavations between 1997 and 1998, portal façade wall, steps accessing the tower located at the southeast corner, rotten wall stones and pointings were renewed [18].

In 2004, following the above mentioned restoration, misapplications were detected. In April 2006, Assoc. Prof. Ahmet Türer presented his Structural Evaluation Report and in May 2006, Tema Engineering presented a Static Analysis and Reinforcement report to Erzurum Council for the Protection of the Cultural and National Property [19]. These reports had revealed the misapplications. It was stated that the steel bays and buttresses placed after the excavation and cleaning works in warehouses had structural problems and damaged the outer walls. It was also figured out that profiles and cross vaults were randomly placed and welded. Also, a drainage problem at the top garden caused water leakage to the warehouses and got the profiles rusted [19].

The cracks on the outer walls of the kitchen section were also threatening. The steel buttresses in this section were not sufficient and were damaging the building. Especially the newly built roof construction in Harem section had fundamental design and construction problems [16]. Roof trusses were halfconstructed [19]. As the structural elements are not strong enough to carry the weight of the roof and to bear the load by snow and wind there is a danger that the structure could twist and damage the building.

The cracks on the walls of the Mosque located in the first court, were covered by plaster. Divergences were observed on the north-south ceiling and the arch and there is water leakage from the cracks on the ceiling. To sum up, it was determined that the carried out restoration works were incompliant with engineering principles. In accordance with the spatial variety of the Palace, the necessity to plan a vertical drainage system and a cover for protecting the inner spaces from outer impacts were set forth [19]. 
As a result of this alarming report, just after 3 years from the improperly realized restoration project in 2007, a new tender was issued for a new restoration project and was once again assigned to Kaba Construction Company. It was aimed to clean up the fundamentally mistaken applications and subsequent additions with this restoration. Eventually, the plate roof cover and its wooden structure with other additional elements damaging the building, were removed [19].

In 2009, the walls were structurally reinforced, and a roof structure covering and an area of $3000 \mathrm{~m}^{2}$, was constructed by Picea obovata wooden beams, covered with tempered, filtered glass, isolating the building both from snow, rain water and thermal effects. In order to cover such a great opening, huge sectioned beams were constructed, however these wooden beams computed with the palace and changed the inner and outer perception of the building. This new layer isolating the palace with contemporary technology was criticized for changing the aesthetic perception and dominating the existing pattern [19].

Prof. Doğan Kuban had stated that a new cover, compatible with the original pattern could be designed with contemporary modern isolation technology [22]. As to Prof. Afife Batur, the restoration of such historic monuments should be carried out with big international organizations and in the long term; she also stated that in Turkey, public institutions and the Chamber of Architects usually remain incapable in these kinds of big restoration organizations. Prof. Hamza Gündoğu had reported the huge mistakes of the restoration of the palace and suggested a space frame structured plexyglass roof instead of the existing one [22]. Subsequent to this restoration which had received criticisms and reactions from local and foreign tourists, in November 2010, the Palace once again had been tendered for restoration and landscape planning. Following the tender, Suat Bakır, Director of Erzurum Council for the Protection of the Cultural and National Property, revealed that Ishak Pasha Palace would undergo the most comprehensive restoration work of all times. It was announced that restoration of dungeon, harem rooms, court hall, mosque and warehouse of the Palace would be initiated in May [23].

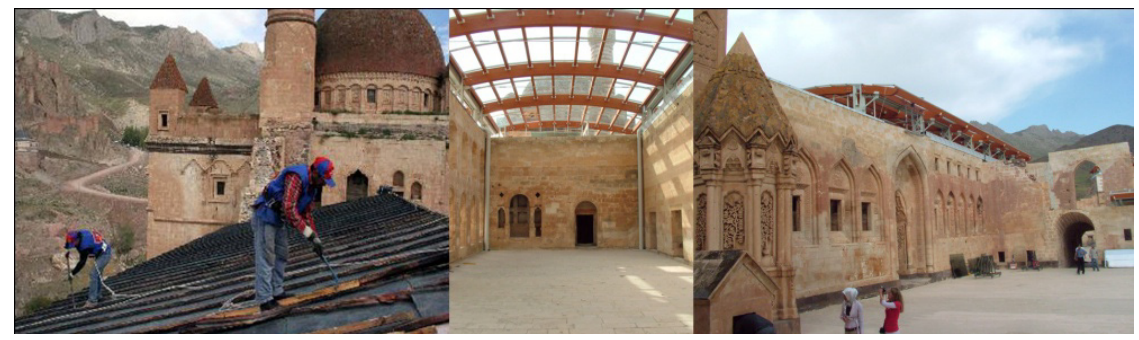

Figure 4: (left) removing the sheet metal and wooden structure of the roof, 2007, (middle, right) the implemented, wooden structured glass roof, 2009.

For the last 48 years, at different periods by various governments numerous interventions and applications for the conservation of the Palace under the name 
of restoration, yield no result. Especially applications which were carried out by trial and error: plate roof in 2006, wooden structured glass roof incompatible with the old pattern in 2009 and final tendering procedure of restoration, caused constructional, structural and aesthetical damages to the Palace.

\section{Conclusion}

Ishak Pasha Palace has been an important world heritage bearing the local features of Anatolian Seljuks, Seljuks and Ottomans in terms of architectural characteristics and plan schemas, and reflecting the social and cultural values of its era.

During the wars and invasions following the 1828 Russian invasion, together with its functioning as a military post between 1925 and 1937 and the use of its stones as spolia in the courtyards of the neighbouring mansions, the palace has survived until 1950s with serious damages and loss of material. Restoration efforts, or most likely to say, applications carried out with trial and error method started by the early 1960s also caused serious damage to Ishak Pasha Palace. The damages caused by those misapplications and improper restoration work conducted on the palace, a candidate for UNESCO World Heritage List, are irreversible.

Together with the delay in development of preservation consciousness and institutionalization, one of the main factors causing Ishak Pasha Palace's current situation is restoration work's changing hands between various contractors in the governorship periods of different governments and the way the work has been awarded to the contractor.

Awarding the work to the lowest bidder has not proved itself to be the best way to conduct a restoration for especially monuments like Ishak Pasha Palace, an important architecture heritage to be inherited to the future generations.

A state institution's direct involving in proper and detailed survey and documentation of the monuments and the design of restoration projects instead of private companies, at least for those stages, could be a solution to improper restoration applications. International competitions where the opinions of a scientific committee and public are taken as evaluation criteria could also be regarded as a good way of attaining proper restoration projects. The application of the project could be awarded to contractors in the condition of serious control of the state.

In order to achieve this goal, decision mechanisms, laws and regulations should be reviewed and revised.

\section{References}

[1] Bingöl, Y., Ishak Paşa Sarayl, Sistem Ofset Yayıncılık: Ankara, pp.1-189, 1998.

[2] Huff, D., Das Felsgrab von Eski Doğubeyazit, İstanbuler Mitteinlungen, AMI:18, Tuebingen, pp.58-86, 1968. 
[3] Gündoğdu, H., Doğubeyazıt İshak Paşa Sarayı, Kültür Bakanlığı Yayınları: Ankara, 1991.

[4] Akok, M., Ağrı Doğubeyazıt İshak Paşa Sarayı Röleve ve Mimarisi, Türk Arkeoloji Dergisi, X-2, pp.30-48, Ankara, 1960.

[5] Eyice, S., Bir Fransız Gizli Ajanı, Amedee Jaubert, Türk Yurdu, 225, İstanbul, pp.742-749, 1955.

[6] Baddeley, JE., The Russian Conquest of Caucasus, Longmans, Green and Co.: London, pp.197-201, 1908.

[7] Eyice, S., İshak Paşa Sarayı, (vol.XX), Türk Ansiklopedisi, Milli Eğitim Basımevi: Ankara, pp.234-235, 1972.

[8] Zühtü, İ., Beyazıt Kalesi İshak Paşa Sarayı, Mimar, 3, Istanbul, pp.12-15, 1934.

[9] Gündoğdu, H., İshak Paşa Sarayı Kazıları, Güneşin Doğduğu Yer: Doğubeyazıt Sempozyumu, ed. O. Belli, Çekül Vakfı Yayınları: Istanbul, pp.227-240, 2004.

[10] Tuğlacı, P., Bayazid, Osmanlı Şehirleri, İstanbul, pp.49-51, 1985.

[11] Texier, C., Description de I'Asie Minuere, 2 Bde, Paris, 1940.

[12] Yurttaş, H., Türk Saray Mimarisi içinde İshak Paşa Sarayı'nın Yeri, Güneşin Doğduğu Yer: Doğubeyazıt Sempozyumu, ed. O. Belli, Çekül Vakfı Yayınları: Istanbul, pp.253-278, 2004.

[13] Eren, C., Selamlık, (vol.XX), Íslam Ansiklopedisi, İstanbul, pp.334-337.

[14] Bingöl, Y., İshak Paşa Sarayı ve Çevresinin Arkeolojik Topografyası, Güneşin Doğduğu Yer: Doğubeyazıt Sempozyumu, ed. O. Belli, Çekül Vakfi Yayınları: Istanbul, pp.215-227, 2004.

[15] Belli, V., E., "The Reasons For The Decay Of The Wooden Consoles In Ishak Pasha Place", II. International Symposium of Mount Ararat and Noah's Ark, ed. O. Belli , Ağrı Valliği Kültür Yayınları, İstanbul, pp.252264, 2009.

[16] Dağtekin, E., Ekinci, B.," Protection Culture In Turkey: "Example of Ishak Pasha Palace", II. International Symposium of Mount Ararat and Noah's Ark, ed. O. Belli , Ağrı Valliği Kültür Yayınları, İstanbul, pp.297-307, 2009.

[17] Özden, S., Çetinor, B., İshak Paşa Sarayı Doğubeyazıt, İlgi, 40, pp.16, 1984.

[18] Gündoğdu, H., İshak Paşa Sarayı Restorasyonunda Son Durum, Aslanapa Armağanı, ed. S. Mülayim, Z. Sönmez, A. Altun., Bağlam Yayınları: Ankara, 129-140,1996.

[19] Selbestoğlu, A., Personal Communication, 23 March 2010, MArch in control, Restoration of Ishak Pasha Palace, Istanbul, Turkey.

[20] DOGUBAYAZIT, www.dogubayazit.biz

[21] JONATHANSHIPLEY, http://jonathanshipley.blogspot.com/

[22] ARKİTERA, www.arkitera.com/h45527-ishak-pasa-sarayi-domates-serasigibi.html

[23] AKTİFHABER, www.aktifhaber.com 